\title{
Fly proof net shed for livestock: A novel concept of physical barrier for integrated management of Culicoides spp. (Diptera: Ceratopogonidae)
}

\author{
B. W. Narladkar ${ }^{1}$ and P. R. Shivpuje ${ }^{2}$
}

1. Department of Veterinary Parasitology, College of Veterinary and Animal Sciences, Maharashtra Animal and Fishery Sciences University, Parbhani, Maharashtra, India; 2. Department of Agricultural Entomology, Marathwada Agricultural University, Parbhani, Maharashtra, India.

Corresponding author: B. W. Narladkar, e-mail: babanar47@gmail.com, PRS: pralhadshivpuje@rediffmail.com

Received: 02-08-2014, Revised: 15-09-2014, Accepted: 25-09-2014, Published online: 04-11-2014

doi: 10.14202/vetworld.2014.899-908. How to cite this article: Narladkar BW, Shivpuje PR (2014) Fly proof net shed for livestock: A novel concept of physical barrier for integrated management of Culicoides spp. (Diptera: Ceratopogonidae), Veterinary World 7(11): 899-908.

\begin{abstract}
Aim: An age old and time tested technique of mosquito net requiring no energy, used by humans since prehistoric period was the inspiration behind this novel technique of fly proof net shed for livestock. With the aim to develop similar type of net shed for animals, which will protect them at night from biting of range of insects from Culicoides midges to mosquitoes, research was undertaken.

Materials and Methods: Net shed with pitch roof (gable type) was erected for use of livestock. The open inlet area was covered with 40 mesh size wire net. The roof at attic level was fitted with hurricane type of ventilator. Shed was used for animals at night hours only. vane anemometer was used for estimation of temperature and wind related parameters. Thermal humidity index (THI) and air changes were calculated as per the standard formulas. Based on these parameters suitability of shed was judged.

Results: It was observed that, due to netting of the shed population of Culicoides and other flies and incidences of their bites at night hours were considerably lowered. As a result, animals were found comfortable, and their body movements undertaken for wiping off these flies were significantly reduced from 196.50 to 22.16. All it accrued to increased milk yield to the tune of $18.97 \%$ in the net shed buffaloes as against control shed. Studies on suitability and comfort to animals were tested by estimating THI and air changes per hour in the net shed, which also revealed the estimates in comfortable regimen and ventilation, remained not much affected despite of netting. Other parameters studied for testing its more accuracy by taking other species of animals as kids, for them also, shed was found suitable through estimation of various physiological and behavioral parameters. Finally, the efficacy of shed was judged on the basis of cost effectiveness. Highly encouraging results on the above said parameters endorsed the effectiveness of the technique.
\end{abstract}

Conclusion: A net shed with pitch roof (gable type) fitted with hurricane type ventilator at its top serves the purpose of a physical barrier to minimize host-pest contact. Observations recorded in the experiment are sound enough to conclude and to recommend the use of net shed for livestock.

Keywords: Culicoides spp., fly proof net shed, integrated pest management, livestock, physical barrier.

\section{I ntroduction}

Importance of Culicoides (Diptera: Ceratopogonidae) as a livestock Pest is of high significance owing to facts that Culicoides are small midges (1-3 $\mathrm{mm}$ ) presenting a huge diversity with more than 1300 species described worldwide [1] of which some $96 \%$ are hematophagous. In addition to bluetongue virus (BTV), Culicoides also transmit African horse sickness (AHS) virus, epizootic hemorrhagic disease virus, equine encephalitis virus, akabane virus, bovine ephemeral fever virus and viruses in the palyam group [2]. However, the two diseases with the greatest veterinary impact among these are undoubtedly BT in bovines and AHS in equines. In India, AHS disease has been reported from Bombay region of Maharashtra [3] and its proven vector is Culicoides imicola midges [4] which is very much prevalent in

Copyright: The authors. This article is an open access article licensed under the terms of the Creative Commons Attributin License (http:// creative commons.org/licenses/by/2.0) which permits unrestricted use, distribution and reproduction in any medium, provided the work is properly cited.
India [5]. Similarly in India, BTV was isolated first time from Culicoides midges about 25 years ago. However, species was not identified [6]. Jain et al. [7] isolated BTV from Culicoides midges (species not identified) from Hisar, Haryana. Recently, from the western state of India (Gujarat) BTV-1 was isolated from Culicoides oxystoma [8] and BTV-16 from West Bengal from Culicoides schultzei [9]. Existence of C. schultzei [10] and isolation of BTV-16 from sheep from Maharashtra [11] explores possibility of C. schultzei as BTV-16 virus vector in Maharashtra. Recently, increasing trend for BTV-16 infection in different species of animals (sheep, goat and cattle) was observed from different states in India [12]. Additionally, Culicoides brevitarsis and C. imicola, which are proven vectors of BTV, occur widely in India [5]. Thus, taking into consideration the above scenario and importance of these tiny midges, it is imperative to control such tiny midges and for which practices of integrated pest management (IPM) can be of great help. 
IPM is the practice of pest management; the whole world was forced to recognize this concept. This was a result of rampant, reckless and indiscriminate use of insecticides resulted in the resurgence of pests that too with their resistance acquired generations. Using various combinations of chemical, biological and cultural techniques with available pest control methods to achieve effective, economical and sustainable pest control in agriculture and veterinary is what IPM means broadly. Environmental consideration is the most important aspect of IPM. Therefore, research on fly proof net shed undertaken, which will serves as a physical barrier and will form an integral part of IPM. It is chemical free, eco and user friendly as well as cost effective.

The hypothesis behind development of "fly proof shed" is the device of mosquito net that has protected human beings from mosquito bites very successfully for ages (vernacular name-Macchardani). Netting of windows with an aim of improved ventilation to horse stable [13] and air ventilation requirement in cattle shed [14] are well documented. Can this time tested technique be put to use for cattle as a physical barrier in the form of Net shed? Can a Net cover to animals will protect them from bites of thousands of Culicoides and other flies like Phlebotomus, Simulium, mosquitoes, etc. during night hours? Can netting will hamper the ventilation? Can hampered ventilation be cope-up with the provision of hurricane ventilator? To verify these hypotheses, a shed covered with a net was devised and tried under this project.

\section{Materials and Methods}

\section{Ethical approval}

Since prime objective of the study was to improve the milk production by curbing the Culicoides midges and other flies nuisance, few managemental manipulations were proposed. The institutional animal ethical committee approved the proposed change in the form of netting of the shed in the design of the study ensuring that no potential harm toward animal welfare was done and without causing any discomfort to the animals.

\section{Preparation of fly proof shed as physical barrier}

A newly conceptualized fly proof shed erected for the animals. The shed provided with brick parapet wall up to the sill level. The area from sill level to pitch roof (up to truss) was entirely covered with nylon mesh with fine nylon 40 mesh size (40 squared holes in one square inch area), rodent proof net (Figure-1). Net shed admeasured $30 \times 30$ feet with pitch roof (gable type) was erected with specifications of: Height as 14 feet and provision of inlet open space for ventilation (construction of parapet brick wall up to sill level: Open space for inlet of air from sill level to roof level (up to truss level in gable type of house) in the ratio of $1: 2.5$, one part brick constructed wall with 2.5 parts open space for inlet of air. The shed top was fitted with one hurricane type ventilator of throat size 24 inch diameter working on the natural wind energy not requiring any artificial energy source like electricity (Figure-2). Hurricane ventilator also functioned for replacing smoke, gas fumes, and hot, humid and stale air with fresh and ambient air. Animal waste such as urine/waste water of shed wash was allowed to pass through outlet, and it was immediately closed with a lid, to avoid entry of the any flies through that route (Figure-2). Since ages the farmers in the state of Maharashtra and in particular Marathwada region adapt practice of cattle rearing in which animals are let loose for gazing during the daylight and are maintained in the sheds during night hours. Simulating the same practice, animals in the net shed and control shed were let loose for grazing during day hours and maintained at night hours in the sheds with tightly closed gate. All the parameters estimated for judging the utility of the shed were studied in comparison with the animals maintained in the half part of the same shed having no provision of net and hurricane ventilator where animals were exposed to the bites of flies throughout night (control shed).

It was assumed prior to experiment that, due to netting of the shed population of Culicoides and other flies and incidences of their bites at night hours are going to be considerably reduced. To estimate such changes, reduction in the average number of Culicoides were counted. Similarly, due to netting ventilation may get hampered and to estimate this, parameters related to comfort such as thermal humidity

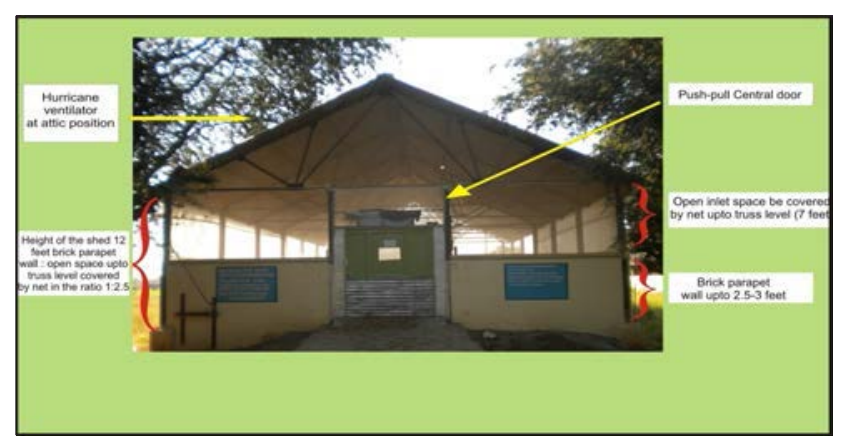

Figure-1: Front view of gable type fly proof net shed.

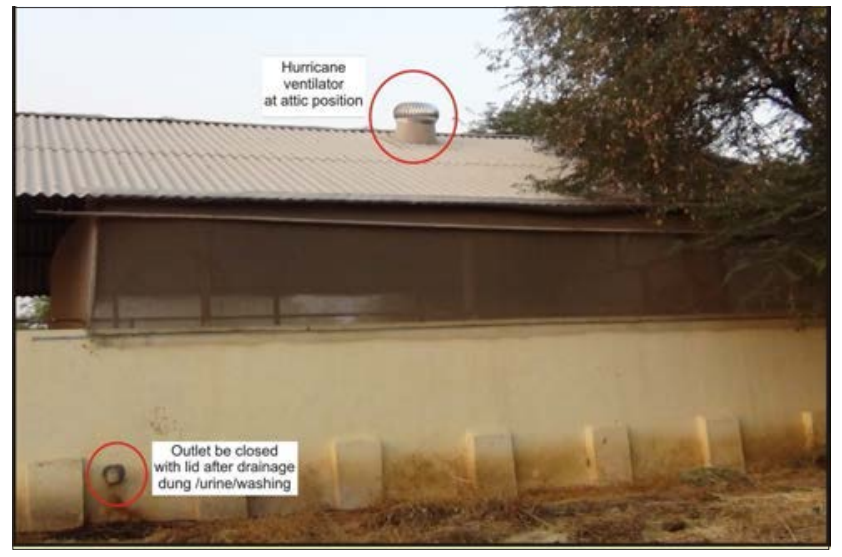

Figure-2: Side view of gable type fly proof net shed. 
index (THI) and air changes per hour were estimated. Once animals in the net shed are comfortable and free from bites, the body movements required for wiping off the flies are going to be reduced substantially, and it was estimated by counting body movements. Absolute gain achieved through comfort to animals is definitely going to be converted into hike in milk yield, which was recorded on a daily basis for complete lactation or say for almost 1 year. Totally the hike in milk yield and additional cost incurred on netting of shed, estimation of cost-effectiveness was undertaken. In Phase II, to judge more accuracy of shed experiment was adapted in kids with different parameters. In the case of kids parameters applied for judging the efficacy and comfort of shed, several parameters related to physiology and behavior were estimated. Overall effect of shed on kids was judged by recording the weight gain. After amalgamating all estimates in buffaloes and kids with various parameters, feasibility of the shed was judged and shed was recommended.

\section{Phase I}

Effect of fly proof net shed was observed on lactating buffaloes with following parameters.

\section{Reduction in the average number of Culicoides}

Parallel collections of the Culicoides flies in the net shed, and control shed were undertaken by using down draught light trap (220 V) equipped with 8 watt black light tube (Figure-3). Light traps were hung in the vicinity of animals [15] for 5 min at the dawn and the dusk. The Culicoides midges were attracted to UV light of the light trap and were collected in the $50 \mathrm{ml}$ sized test tubes. Count was recorded once in a week for 52 weeks in a calendar year covering all the three seasons occurring in this region (Total 104 observations).

\section{Recording of milk yield}

Total milk production (morning and evening) on a daily basis from six Matathwadi buffaloes in net shed and six from control shed taken into account. The

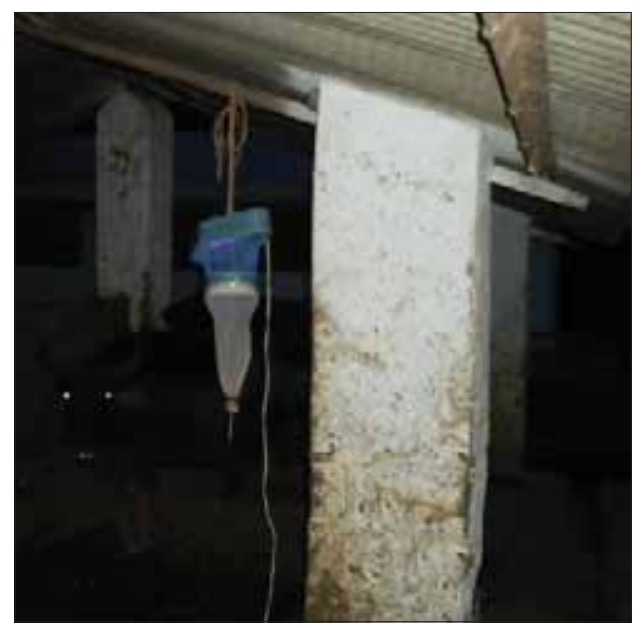

Figure-3: Down draught light trap (220 volts) equipped with 8 watt black light tube. buffaloes maintained in both shed were having almost identical average age and parity number. Animals from both shed were receiving same quality and quantity of food with all similar routine rearing patterns.

\section{Estimation of THI and air changes (comfort parameters)}

These two parameters were estimated with the help of vane anemometer (make Testo Ltd.) in the net shed and in control shed at $7.00 \mathrm{~h}$ and $14.00 \mathrm{~h}$.

The THI was estimated by the formula described by Bianca [16]:

$\mathrm{THI}=(0.35 \times \mathrm{Tdb}+0.65 \times \mathrm{Twb}) \times 1.8+32$

Whereas,

THI: Thermal humidity index

Tdb: Temperature recorded from dry bulb thermometer

Twb: Temperature recorded from the wet bulb thermometer

Whereas, air changes per hour were estimated by the formula by Wheeler [13].

$\mathrm{RV}=(\mathrm{AV}) \times(\mathrm{OV})$

$\mathrm{AC}=(\mathrm{RV}) \div(\mathrm{SV})$

\section{Whereas}

RV: Ventilation rate, is measured in cubic feet per minute $(\mathrm{cfm})$ and is a product of AV multiplied by $\mathrm{OV}$

AV: Air velocity, is the speed of air entering in the shed and measured in feet per minute

OV: Opening area of ventilation, is the area covered by net (net shed)/open area (control shed) for movement of air and is measured in square feet

SV: Shed air volume, is a product of length $\times$ width $\times$ roof height in feet of net/control shed

AC: Air changes, is the magnitude of RV divided by SV and is measured on hourly bases (per hour).

\section{Geographic location of study place for present project}

The research conducted in the present project has much relevance with the environmental conditions under which shed has been erected. Hence, it will not be out of context to mention the geographic location of the present study place. Marathwada (Parbhani) region of Maharashtra state, the place of present study lies between latitude $17^{\circ} 35^{\prime} \mathrm{N}-20^{\circ} 40^{\prime} \mathrm{N}$ longitudes $70^{\circ} 40^{\prime}-78^{\circ} 15^{\prime} \mathrm{E}$, mean sea level - $40.9 \mathrm{~m}$, comprising of eight districts in the deccan plateau zone, is basically an intense agrarian region having rural setting. Climatologically Marathwada region is categorized as semi-arid on an annual basis. It is humid to per-humid during monsoon, sub-humid to semi-arid during winter and arid during the summer season. The corresponding distribution pattern of annual rainfall (500-1100 mm) 
is $75-85 \%, 10-15 \%$ and $6-10 \%$, respectively. The wet monsoon (weeks 23-44, $4^{\text {th }}$ June- $4^{\text {th }}$ November) period alternates with long rain free cold winter (weeks 45-9, $5^{\text {th }}$ November- $4^{\text {th }}$ March). The $\left(12-18^{\circ} \mathrm{C}\right)$ minimum temperature and $40-45^{\circ} \mathrm{C}$ max. Is observed during the summer (weeks 10-22, $5^{\text {th }}$ March-3 ${ }^{\text {rd }}$ June), having appreciable temporal and spatial variability, the typical characteristics of semi-arid climate. The thermo-aerodynamics conditions are conducive for existing agro-eco systems during monsoon and winter, with moderate and severe limitations of soil moisture availabilities during winter and summer seasons [17].

\section{Recording of body movements}

Once a week at during dawn and dusk times and at night times (20-21 h), the time when bites of Culicoides and other flies were at its peak, were recorded. To record the movements of various body parts of the animals a 10 min video was shot. Data of video recording was transferred to laptop and body movement counts were recorded. The animal make movements of body parts such as tail, ear, pinna, neck and skin for wiping off the flies sitting on the body and biting. If the energy wasted in wiping off the flies is conserved, it will get utilized in enhancing their production.

\section{Estimation of cost effectiveness of fly proof Shed}

Economics was worked out on following basis of (a) additional cost of netting of the shed for 10 animals, (b) gain in milk yield due to netting of shed, (c) assuming the total gain of milk quantum with 18.97\% hike, and (d) cost of the milk @ Rs. 29/L.

\section{Phase II}

Effect of fly proof net shed observed in Osmanabadi goat kids for 6 months duration covering part of the summer, part of the winter season and entire rainy season. The parameters studied:

\section{Estimation of body weight gain}

A separate experiment with twelve healthy Osmanabadi goat kids of 3-4 months of age, separated in the two equal treatment groups of six each (two males + four females kids), were maintained in the control shed and in net shed. The kids were provided with standard management practices in terms of space, and the feed was provided ad libitum. For assessing food and water intake kids were provided with measured quantities of feed and water to a group of six kids [18]. For assessing growth rate, the weight of individual kid was taken at weekly interval from each shed, and average growth rate was calculated for both the groups.

\section{Estimation of physiological parameters}

Physiological parameters viz. body temperature $\left({ }^{\circ} \mathrm{F}\right)$, pulse rate (beat per minute) and respiration rate (breath per minute) of kids were recorded on weekly basis by following standard procedures [19] at $7.00 \mathrm{am}$ and $14.00 \mathrm{pm}$.

\section{Estimation of behavioral parameters}

Behavior was defined by Goetsch et al. [20] as the response of an individual to its environment. The behavioral observations were recorded on a weekly basis for $24 \mathrm{~h}$ by keeping animals under surveillance. During $24 \mathrm{~h}$ various activities pertaining to sitting and resting, feeding and rumination were recorded by personal observations. These parameters were recorded as visual observations [21] in terms of time spent by individual kid in a particular activity. Visual observations were recorded from long distance to avoid any disturbance to kids. New technology was adapted in the form of indoor/outdoor CCTV cameras located in housing pens [22].

\section{Results and Discussion}

The identification and confirmation of Culicoides species carried out at laboratory level followed by molecular identification and DNA bar coding at NBAII Bangalore, revealed the presence of three species Culicoides namely (1) Culicoides peregrinus Kieffer, 1910, (2) C. schultzei Enderlein, 1908 and (3) Culicoides actoni Smith, 1929. Along with three Culicoides species prevalence of Sergentomyia punjabensis (Phlebotomus), Simulium truncatum and Aedes aegypti mosquitoes have been noted from the region. All these dipteran fly pests particularly bites at night time and except mosquitoes all are tiny sized and cannot enter through the net (40 mesh size net), which was used for preparing the fly proof net shed. Therefore, it was ascertained that, fly proof net shed will be of immense use in protecting the livestock under shed, not only from Culicoides but additionally from all above mentioned dipteran pests.

\section{Results and discussion on Phase I}

Data in the Table-1, explains that during all three seasons of the year significant reduction were observed in the midge population in the net shed. During the monsoon the midge population was so high that even $1 \mathrm{~min}$ opening of the door for feeding and other management resulted into the entrance of several midges. As a result, presence of 5 flies was recorded in the net shed. The net shed is a sort of measure which effectively minimizes the pest-host contact (Figures-4 and 5). Functioning of net shed is analogous to the use of insecticide-treated mosquito nets, recommended by World Health Organization (WHO) for human use. Surveys undertaken by WHO showed dramatic reductions in the number of cases of malaria in communities using insecticide-treated mosquito nets during nights. Regular use of treated nets has also shown a reduction in child mortality by about 25\% [23]. The net shed constructed for animals was used at night hours only instead of using it round the clock. In any system of animal husbandry used in a particular region, animals are kept under roof at least during nights. It can be employed to any type of housing, may it be open/semi-open even may 
it be prepared from local shrub material in the form of hut.

Average milk yield hike in the net shed buffaloes recorded to the extent of $18.97 \%$ (Table-2). Such hike in milk yield can contribute considerably to the total quantity of milk produced. A 2-3 fold hike in milk yield was reported in a success story published by FAO [24] on "Netting flies and mosquitoes protects livestock, boosts milk yields in Rome," by using insecticide-impregnated nets. Specialty of present project study was that, it suggested the use of net without impregnation of net in chemical pesticides, helps in saving the environment from hazardous chemicals.

Regarding THI, no significant variation in control and net shed recorded indicating thorough comfort to net shed animals at par with control shed animals (Tables-3 and 4). According to Bouraoui et al. [25] the THI below 68 indicates most comfortable situation (without any heat stress), while THI between 72 and 78 as mild stress, $79-88$ as moderate, $89-98$ as severe stress and $>98 \mathrm{THI}$ means animal is dead. In this context THI of summer and monsoon season falls under mild to moderate category, while THI of winter falls under most comfortable category in both the sheds. Productivity of animals is primarily the product of the interaction of its genetic makeup and the environment in which it develops. The high ambient temperature together with humidity and solar radiation constitute climatic stress that affect the physiology response, which lowers the performance of animals in terms of growth, milk production and reproduction

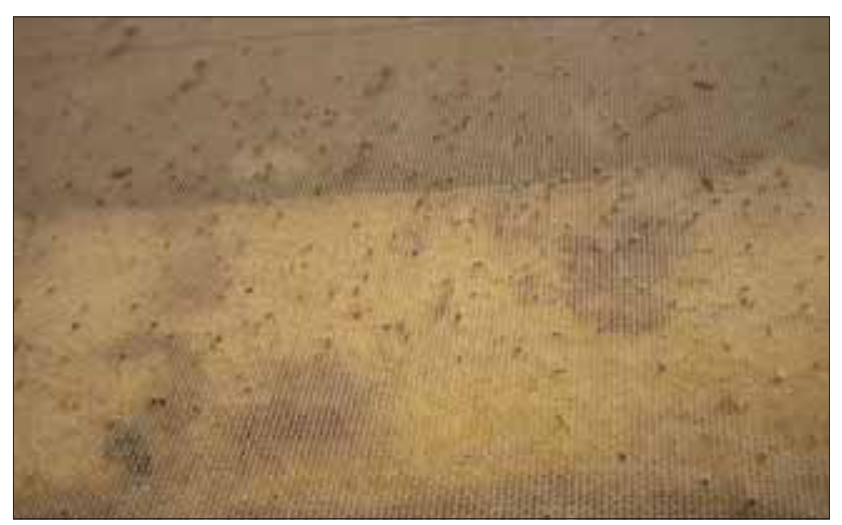

Figure-4: Netting prevented entry of Culicoides midges in the buffalo shed.

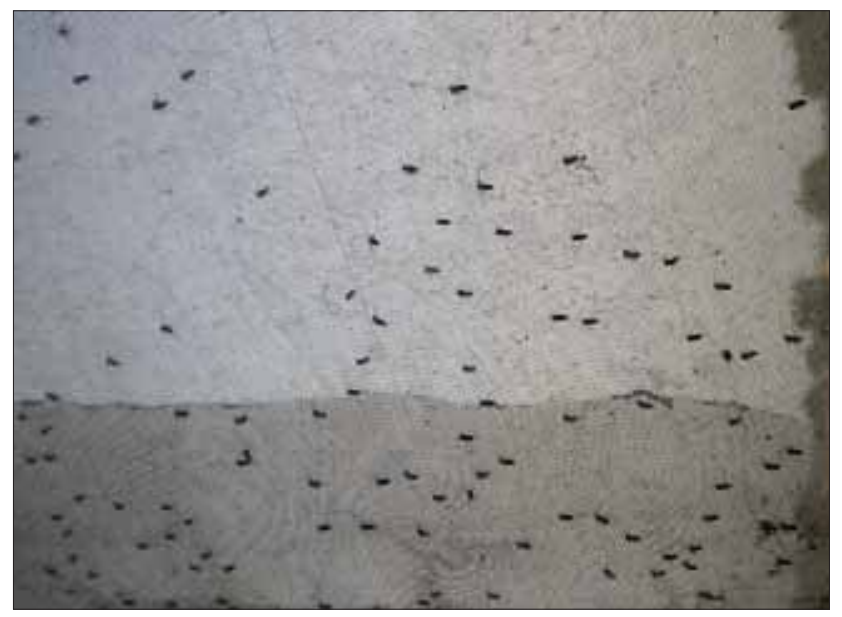

Figure-5: Netting prevented entry of mosquitoes in the buffalo shed.

Table-1: Reduction in the Culicoides midges population in fly proof shed.

\begin{tabular}{|c|c|c|c|c|c|c|}
\hline \multirow[t]{2}{*}{ Parameter } & \multicolumn{2}{|c|}{ Summer $(n=13) @$} & \multicolumn{2}{|c|}{ Winter $(n=17)^{\circledR}$} & \multicolumn{2}{|c|}{ Monsoon $(n=22){ }^{\circledR}$} \\
\hline & Net $\#$ & Control\$ & Net ${ }^{\#}$ & Control\$ & Net $^{\#}$ & Control\$ \\
\hline Mean $₫ \pm S E$ & Nil & $2.00 \pm 0.57$ & $2.33 \pm 0.49$ & $\begin{array}{c}19.56 \pm 2.09 \\
(8-22)\end{array}$ & $5.00 \pm 1.46$ & $51.50 \pm 2.44$ \\
\hline $\begin{array}{l}\text { Range } \\
\text { t-statistic }\end{array}$ & $\left.5.888^{(H S}\right)$ & & 17.688 (HS) & & 15.418 (HS) & \\
\hline t-table $(0.05)$ & 2.179 & & 2.120 & & 2.080 & \\
\hline t-table $(0.01)$ & 3.055 & & 2.921 & & 2.831 & \\
\hline
\end{tabular}

\#Average number of Culicoides found in the fly proof animals shed (shed covered in net), \$Average number of Culicoides found in the shed of control animals (without net), @Count of the Culicoides was recorded once in a week for 52 weeks in a calendar year 2010 covering all the three seasons occurring in this region (Total 104 observations), \&Average number of Culicoides collected in the light trap within $5 \mathrm{~min}$ at dawn and dusk. HS=Highly significant $(p>0.01)$, SE: Standard error

Table-2: Average hike in milk yield in Marathwadi buffaloes.

\begin{tabular}{|c|c|c|c|c|}
\hline Parameter & $\begin{array}{l}\text { Average milk yield } \\
\text { in the control shed } \\
\text { liter/ day/ buffalo }\end{array}$ & $\begin{array}{l}\text { Average milk yield of } \\
\text { the buffaloes in the net } \\
\text { shed liter/ day/ buffalo }\end{array}$ & t-statistic & t-table \\
\hline Initial reading & $2.345 \pm 0.34(1.50-3.00)$ & $2.342 \pm 0.33(1.50-3.00)$ & 1.000 & $5 \%: 2.201$ \\
\hline $\begin{array}{l}\text { Reading after } 1 \text { year } \\
\text { data during } 2010\end{array}$ & $2.335 \pm 0.28(1.48-3.00)$ & $2.786 \pm 0.42(1.70-3.20)$ & 4.565 & $1 \%: 3.106$ \\
\hline $\begin{array}{l}\text { Average } \\
\text { approximate }\end{array}$ & \multirow{3}{*}{\multicolumn{4}{|c|}{$\begin{array}{l}\text { 1. Hike of } 0.440 \mathrm{ml} / \text { buffalo/day (Approximate hike of } 18.97 \% \text { ) in net shed between initial } \\
\text { milk yield and milk yield after } 1 \text { year } \\
\text { 2. Hike of } 0.450 \mathrm{ml} / \text { buffalo/day (Approximate hike of } 19.27 \% \text { ) in net shed buffalo from } \\
\text { control shed in milk yield after } 1 \text { year } \\
\text { 3. Reduction of } 0.010 \mathrm{ml} / \text { buffalo/day in control shed between initial milk yield and milk yield } \\
\text { after } 1 \text { year }\end{array}$}} \\
\hline $\begin{array}{l}\text { percent hike in milk } \\
\text { yield }\end{array}$ & & & & \\
\hline & & & & \\
\hline Remarks & \multicolumn{4}{|c|}{$\begin{array}{l}\text { Data can have slight variation due to factors such as age, breed, stage of lactation, total } \\
\text { number of parturition etc. }\end{array}$} \\
\hline
\end{tabular}


etc. [26]. Increase in the production of milk yield shall be considered as comfortable THI in net shed. Similarly, from the data (Table-5), it appears that there was a reduction in air changes per hour in the net shed as compared to control shed. More particularly air changes during the winter were quite low as compared to control. However, reading together of THI and air changes during the winter season (Tables-5 and 6), it can be inferred that animals during the winter season were in a comfortable situation without any stress.

The movement of tail, ear pinna, neck and skin is performed by the animals for wiping off the flies biting/sitting on the body. The painful bites of these flies distract animals from feeding; suck their blood and cause psychological disturbances all this leads to loss of weight, affect overall health, production, and reproduction. It reveals from data in Table-7, that significantly less (almost 9 times) body movements were observed in the animals from net shed, resulting in saving of energy and hike in milk production.

The economics worked out on the following basis indicated the cost effectiveness of the net shed.

a. Cost for netting of the shed for 10 animals: Rs. 33,350 b. Gain in milk yield due to netting of shed Assuming the total gain of milk quantum: $1356.78 \mathrm{~L}$ From 10 buffaloes (i.e. $2.345 \times 10 \times 305=7152.25 \mathrm{~L}$ with $18.97 \%$ hike $=$ Ref Table-2)

c. Cost of milk (Data from Animal Husbandry and Dairying Department of Maharashtra Government 2011. Proportionate hike in cost for netting of shed and cost of milk is expected at the time of erection) @ Rs. 29/L, total amounts (1356.78 L × Rs. 29=39346.67): Rs. 39346.67.

The cost of netting the shed (Rs. 33350) can be reimbursed within 1 year. Additional income of Rs. 6596.67/10 buffaloes (Rs. 39346.67-33350.00). Further shed will continue to protect the animals, at least for 10 more years, from many vector borne diseases and psychological disturbances.

\section{Results and discussion on Phase II}

Significant difference was observed between overall average body weight gain of Osmanabadi goat kids reared under net shed and control shed. This significant difference can be attributed to the better rearing environment in net shed, without any stress of heat. They were able to dissipate the heat stored during day time, at night hours and thus were able to alleviate the

Table-3: Comparison of THI estimated in the net shed and control shed.

\begin{tabular}{|c|c|c|c|c|c|c|c|}
\hline \multirow[t]{2}{*}{ Season } & \multicolumn{2}{|c|}{ Morning } & \multicolumn{2}{|c|}{ Afternoon } & \multirow[t]{2}{*}{ CD $5 \%$} & \multirow[t]{2}{*}{ CD 1\% } & \multirow[t]{2}{*}{ Stat } \\
\hline & Net & Control & Net & Control & & & \\
\hline Summer & 74.850 & 74.475 & 80.800 & 81.650 & 1.240 & 1.630 & No significant difference \\
\hline Monsoon & 74.200 & 73.875 & 78.650 & 78.775 & & & \\
\hline Winter & 67.225 & 67.225 & 76.725 & 77.225 & & & \\
\hline
\end{tabular}

$\mathrm{THI}=$ Thermal humidity index

Table-4: Comparison of THI estimated in the net shed and control shed during the three seasons.

\begin{tabular}{|c|c|c|c|c|c|c|c|}
\hline Parameter & Morning & Afternoon & Net & Control & Summer & Monsoon & Winter \\
\hline & $71.975^{m}$ & $78.978^{n}$ & 75.403 & 75.535 & $77.947^{a}$ & $76.375^{b}$ & $72.100^{c}$ \\
\hline CD 5\% & $0.5 c$ & & & & 0.625 & & \\
\hline \multirow[t]{2}{*}{ CD $1 \%$} & 0.661 & & 0.661 & & 0.815 & & \\
\hline & \multicolumn{2}{|c|}{$\begin{array}{l}\text { Significant difference between } \\
\text { THI of morning - afternoon }\end{array}$} & \multicolumn{2}{|c|}{$\begin{array}{l}\text { Non-significant difference between } \\
\text { net and control Shed THI }\end{array}$} & \multicolumn{3}{|c|}{$\begin{array}{c}\text { Significant difference between } \mathrm{THI} \\
\text { of three seasons }\end{array}$} \\
\hline
\end{tabular}

$\mathrm{THI}=$ Thermal humidity index

Table-5: Comparison of air changes estimated in the net shed and control shed.

\begin{tabular}{|c|c|c|c|c|c|c|c|}
\hline \multirow[t]{2}{*}{ Season } & \multicolumn{2}{|c|}{ Morning } & \multicolumn{2}{|c|}{ Afternoon } & \multirow[t]{2}{*}{ CD $5 \%$} & \multirow[t]{2}{*}{ CD 1\% } & \multirow[t]{2}{*}{ Stat } \\
\hline & Net & Control & Net & Control & & & \\
\hline Summer & $5.726^{a}$ & $13.903^{b}$ & $6.315^{\mathrm{m}}$ & $15.443^{n}$ & 4.596 & 6.080 & Different superscripts shows \\
\hline Monsoon & $2.051^{p}$ & $2.728^{q}$ & 5.219 & 9.696 & & & significant difference in a row for \\
\hline Winter & $2.282^{k}$ & $5.617^{\prime}$ & $2.336^{x}$ & $5.398^{y}$ & & & comparison between allied parameter \\
\hline
\end{tabular}

Table-6: Comparison of air changes estimated in the net shed and control shed during the three seasons.

\begin{tabular}{|c|c|c|c|c|c|c|c|}
\hline Parameter & Morning & Afternoon & Net & Control & Summer & Monsoon & Winter \\
\hline & $4.513^{a}$ & $8.783^{b}$ & $4.863^{m}$ & $8.423^{n}$ & $10.347^{x}$ & $4.937^{y}$ & $4.652^{y}$ \\
\hline CD 5\% & 1.875 & & & & 2.293 & & \\
\hline \multirow[t]{2}{*}{ CD $1 \%$} & 2.488 & & & & 3.040 & & \\
\hline & \multicolumn{2}{|c|}{$\begin{array}{l}\text { Significant difference } \\
\text { between air changes of } \\
\text { morning - afternoon }\end{array}$} & \multicolumn{2}{|c|}{$\begin{array}{c}\text { Significant difference } \\
\text { between net and control } \\
\text { shed }\end{array}$} & \multicolumn{3}{|c|}{$\begin{array}{l}\text { Significant difference between air } \\
\text { changes of three seasons }\end{array}$} \\
\hline
\end{tabular}


effect of stress, resulting in body weight gain (Table-8). The research have shown that the depressive effect of ambient temperature is exhibited when it exceed $25^{\circ} \mathrm{C}$ [27] and in such situation feed intake decreases due to heat stress. It was observed in the present project that the average feed intake was at par in kids reared under net and control shed (Table-9). Thus, it is clear that kids were comfortable in net shed as an equal to control shed even during the hottest month May. According to Dahlanuddin et al. [28] the increase in ambient temperature results in increased water intake. However, the observations in this project reveal that the average water intake by kids in net shed was significantly lower as compared to those in control shed. It indicates that kids in net shed might not have experienced any stress and therefore it was not reflected in increased water intake (Table-9). According to Patil et al. [29], providing ventilation, either one or two ventilators per house, reduces the micro temperature and therefore was responsible for less water intake in comparison with those house, which had no ventilation. Proper housing ameliorates the heat load by modifying the micro-environment and thereby saving the additional water requirement. Application of hurricane ventilator might have worked on similar analogy and helped to maintain water intake of kids at par with control group kids. Therefore, in any type of the housing system, deployment of hurricane ventilator, which has an additional advantage for improving the microclimate in the shed and hence it is recommended.

Estimated physiological parameters in kids showed non-significant variation proving that net shed was suitable for animals as their physiological parameters remained unaltered (at par to control) (Table-10).
According to Srikandakumar and Johnson [30] effect of heat stress in HF cows, resulted in increased respiration rate and rectal temperature. In a review article Silanikove [31] described the effect of heat stress on body physiology of animals. According to him, high ambient temperatures, high direct and indirect solar radiation, and humidity are environmental stress factors that impose strain on animals. Despite having well-developed mechanisms of thermoregulation, ruminants do not maintain strict homeothermic under heat stress. There is unequivocal evidence that hyperthermia is deleterious to any form of productivity, regardless of breed, and stage of adaptation. The well-recognized effect of raised body temperature is an adaptive depression of the metabolic rate associated with reduced appetite. Thus, in domestic ruminants a rise of body temperature marks the transition from aversive stage to noxious stage. Physiological (sweating, panting), hormonal (cortisol, thyroid gland activity), and behavioral thermoregulatory responses are also affected greatly. Factors such as water deprivation, nutritional imbalance and deficiency may exacerbate the impact of heat stress. In this context, non-significant rectal temperature difference between net shed and control shed kids is indicative of no heat stress to kids in the net shed and their body physiology was functioning well without any effect of heat stress. The increased respiration rate is one of the first reactions of the animal to the increased environmental temperature stress. The increased respiration rate due to heat stress enables the animal to dissipate the excess body heat by vaporizing more moisture through expired air. It also utilizes increased respiration rate as a mean to cool the body, whereas the lower respiration

Table-7: Body movements within 10 min time in net and control shed.

\begin{tabular}{lccl}
\hline Body part & Net shed & Control shed & CD \\
\hline Tail & $10.50 \pm 5.48(1-370)$ & $90.16 \pm 12.78(47-134)$ & $1 \%: 34.426$ \\
Neck & $3.16 \pm 1.07(0-7)$ & $25.83 \pm 8.04(7-56)$ & $5 \%: 25.774$ \\
Ear & $6.50 \pm 1.76(1-11)$ & $52.83 \pm 8.15(29-85)$ & all parameters differs \\
Skin & $2.00 \pm 1.18(0-7)$ & $29.33 \pm 7.71(9-52)$ & significantly except \\
Total & $22.16 \pm 8.53(3-62)$ & $196.50 \pm 22.88(116-260)$ & neck movement \\
\hline
\end{tabular}

Table-8: Weight gains at the end of $10^{\text {th }}$ week in kids under net and control shed.

\begin{tabular}{|c|c|c|c|c|c|c|}
\hline \multicolumn{3}{|l|}{ Kids in net shed } & \multicolumn{3}{|c|}{ Kids in control shed } & \multirow[t]{2}{*}{ CD } \\
\hline $\begin{array}{l}\text { I nitial } \\
\text { weight }\end{array}$ & $\begin{array}{l}\text { Weight at the end } \\
\text { of } 10^{\text {th }} \text { week }\end{array}$ & $\begin{array}{l}\text { Gain in weight } \\
\text { at the end of } \\
10^{\text {th }} \text { week }\end{array}$ & I nitial weight & $\begin{array}{l}\text { Weight at the end } \\
\text { of } 10^{\text {th }} \text { week }\end{array}$ & $\begin{array}{l}\text { Gain in weight } \\
\text { at the end of } \\
10^{\text {th }} \text { week }\end{array}$ & \\
\hline $7.33 \pm 0.60(6-10)$ & $9.56 \pm 0.55(7.7-11.7)$ & $2.23^{a}$ & $6.42 \pm 0.60(5-9)$ & $8.15 \pm 0.57(6.8-10.6)$ & $1.73^{b}$ & 0.42 \\
\hline
\end{tabular}

Table-9: Feed and water intake by kids in the net and control shed.

\begin{tabular}{lccl}
\hline Parameter & Net shed & Control shed & CD \\
\hline Feed intake in & $19.302 \pm 0.307(17.000-22.000)$ & $19.667 \pm 0.283(17.800-22.000)$ & Non-significant difference \\
$24 \mathrm{~h} \mathrm{Kg} /$ day/six kids & & & \\
Water intake in & $6.302^{\mathrm{a}} \pm 0.125(5.00-7.80)$ & $7.532^{\mathrm{b}} \pm 0.0 .114(5.50-8.20)$ & Sig. difference \\
$24 \mathrm{~h}$ liter/day/ & & CD at $1 \%-0.452$ \\
six kids & & CD at $5 \%-0.346$ \\
\hline
\end{tabular}


rate during rainy or winter season helps in conservation of heat in animal body. From data of Table-11 it is assessed that, non-significant difference in the respiration rate of net shed kids and control kids, indicated comfort to the kids in the net shed without any stress of heat, otherwise it might have reflected in the increased respiration rate. On similar grounds the non-significant difference of pulse rate and heart rate in the kids of two groups can be justified.

Data from the Table-11 shows the estimated behavioral parameters such as rumination and sleeping hours exhibited significant variation of higher magnitude than the control shed kids indicating the higher comfort levels to the kids in the net shed. Feeding hours showed non-significant variation showing net shed was suitable for animals and was at par with control shed animals.

\section{Behavioral parameters in the kids and its analogous comparative analysis with buffaloes}

Physical accommodations for dairy cattle should have a relatively dry area for the animals to lie down and should be comfortable and conducive to cows for lying as many hours of the day as they desire [32]. Recent research work also indicated that blood flow to the udder, which is related to the level of milk production, is substantially higher (28\%) when a cow is lying than when a cow is standing [33]. In the light of these two findings, the results obtained in net shed buffaloes in terms of hike in milk yield of around 18.97 $\%$ indicates that, buffaloes in the shed must have full physiological rest and ample comfort of lying down as it appeared from increased resting hours observed in the net shed kids (6.166 h) against $4.656 \mathrm{~h}$ in control kids. Thus it can be inferred that, net shed helps in enhancing milk production by two ways: (a) it conserves the energy wasted in wiping off the flies and (b) animals can comfortably rest by lying down for more period without disturbances caused from annoyance and worries due to bite of flies. In contrast to present study Clavate et al. [34], who have attempted use of net as a physical barrier for protection from C. imicola, however he expressed concerned over reduced air flow.

In regards to physiological and behavioral parameters three important observations are needed to be discussed. (1) The understanding of the behavioral standards and the physiological knowledge of the animals in a tropical environment are essential for the development of the management practice, in view of a better performance of the animals [35], (2) thermolysis mechanism considered to be the most effective for the ruminants bred in tropical areas. Part of such a mechanism occurs by means of the airways tracts and partly by the skin way. Therefore, the occurrence of this thermic stress can be diagnosed by the increase of the rectal temperature, respiratory rate and sweat rate. Some mechanisms that combat the excessive temperature are the increase of the respiratory rate, food intake reduction, water intake increase and activity decrease at the warmest hours of the day [36], and (3) By measuring the rectal temperature and the respiratory rate of an animal it is possible to infer about its thermic comfort in a certain environment; based on these data, it is possible to search for options to minimize the stress [37]. In the light of above three observations, when present study observations were analyzed, it can be inferred that (a) study of such parameters is essential when any modification/alteration is to be made in the housing system, may be for goats or lactating cattle and buffaloes, (b) there is need for research on such modification/alteration in the housing system, which will reduce the thermal stress, will provide maximum comfort to animals and will result in improvement in health, production and reproduction and (c) modification in the form of fly proof net shed, which will act as physical barrier for preventing pest-host contact and will not create any thermal stress to animals of any host species needs to be encouraged.

Criteria for a satisfactory environment for dairy cattle includes thermal comfort (effective environmental temperature), physical comfort (injury-free space and contact surfaces), disease control (good ventilation and clean surroundings), and freedom from fear. Cattle can thrive in almost any region of the world if they are given ample shelter from excessive wind, solar radiation, and precipitation [38]. Heat stress affects the comfort of cattle more than the cold stress. Meaning of freedom from fear may include unwanted sound, annoyance, worries and buzzing sound of flies, etc. Provision of net shed keeps animals free from

Table-10: Physiological parameters in kids under net and control shed.

\begin{tabular}{lcccc}
\hline Parameter & Net shed kids & Control shed kids & CD & Result \\
\hline Heart rate & $81.66 \pm 0.97(78-85)$ & $82.50 \pm 0.76(80-85$ & 2.57 & NS \\
Pulse rate & $74.83 \pm 0.47(73-76)$ & $74.66 \pm 0.49(73-76)$ & 1.58 & NS \\
Respiration & $14.16 \pm 0.47(13-16)$ & $14.16 \pm 0.47(13-16)$ & 1.43 & NS \\
Rectal temperature & $101.46 \pm 0.17(100.8-102)$ & $101.23 \pm 0.24(100.2-102)$ & 0.58 & NS \\
\hline
\end{tabular}

Table-11: Behavioral parameters in kids under net and control shed.

\begin{tabular}{lcccc}
\hline Parameter & Net shed kids & Control shed kids & CD & Result \\
\hline Rumination hours & $2.553 \pm 0.37(1.57-4.12)$ & $1.975 \pm 0.30(1.12-3.12)$ & 0.877 & $\mathrm{~S}$ \\
Feeding hours & $3.496 \pm 0.16(3.12-4.03)$ & $3.696 \pm 0.11(3.4-4.12)$ & 0.455 & NS \\
Sleeping/resting hours & $6.166 \pm 0.53(4.41-7.02)$ & $4.656 \pm 0.88(2.16-8.11)$ & 1.450 & $\mathrm{~S}$ \\
\hline
\end{tabular}


annoyance and worries caused by many fly species including Culicoides spp.

\section{Conclusions}

Results of the research undertaken for developing the net shed for animals as a physical barrier to minimize host-pest contact, revealed that, due to netting of the shed population of Culicoides and other flies and incidences of their bites at night hours were considerably lowered. As a result, animals were found comfortable, and their body movements undertaken for wiping off these flies were significantly reduced from 196.50 to 22.16. All it accrued to increased milk yield to the tune of $18.97 \%$ in the net shed buffaloes as against control shed. Studies on suitability and comfort to animals were tested by estimating Thermal Humidity Index and Air Changes per hour in the net shed, it also revealed the estimates in comfortable regimen and ventilation remained not much affected despite of netting. More accuracy of net shed towards animals were studied by maintaining other species of animals as kids in the shed, for them also, shed was found suitable after estimation of various physiological and behavioral parameters. In all, observations recorded in the present experiment are sound enough to conclude and to recommend the use of net shed for livestock.

\section{Authors' Contributions}

BWN being Principal Investigator (PI) of the research project conceptualized and implemented the technical program with the help of Junior research fellow. BWN collected, processed and analyzed the data and submitted it in the form of present research article. PRS being Co-PI is involved in the finalization of the technical program and involved in validation and confirmation of data. PRS being recognized taxonomist, based on morphological features confirmed all insect species reported in this article. Both authors read and approved the final manuscript.

\section{Acknowledgments}

The authors greatly acknowledges and keep on record the gratitude toward Department of Biotechnology, Government of India, New Delhi for their valuable financial help for the project. Authors are also thankful to MAFSU Nagpur authorities for their encouragement. Thanks are due to Associate Dean and Professor of LPM, College of Veterinary and Animal Sciences, Parbhani, for the facilities provided.

\section{Competing Interests} interests.

The authors declare that they have no competing

\section{References}

1. Borkent A. (2014). World species of biting midges (Diptera: Ceratopogonidae). Available from: http://wwx.inhs.illinois. edu/files/9913/9144/3328/CeratopogonidaeCatalog.pdf Accessed on 23-07-2014.
2. Mellor, P., Baylis, M. and Mertens, P. (2009) Bluetongue. Elsevier, Oxford, UK.

3. Gorhe, D.S., Khot, J.B., Paranjpe, V.L. and Manjrekar, S.L. (1965) Observations on the outbreak of South African horse sickness in India during 1960-1961. Bombay Vet. Coll. Mag., 5-15.

4. Mellor, P.S. (1993) African horse sickness: transmission and epidemiology. Vet. Res., 24: 199-212.

5. Ilango, K. (2006) Bluetongue outbreak in Tamil Nadu, Southern India: Needs to study the Indian biting midge, vectors, Culicoides Lattreille (Diptera: Ceratopogoniae). Curr. Sci., 90: 163-167.

6. Prasad, G., Jain, N.C. and Gupta, Y. (1992) Bluetongue virus infection in India: A review. Rev. Sci. Tech. Off. Int. Epizoot., 11(3): 699-711.

7. Jain, N.C., Prasad, G., Gupta, Y. and Mahajan, N.K (1988). Isolation of bluetongue virus from Culicoides sp. in India. Rev. Sci. Tech. Off. Int. Epizoot., 7(2): 375-378.

8. Dadawala, A.I., Biswas, S.K., Rehman, W., Chand, K., De, A., Mathapati, B.S., Kumar, P., Cauhan, H.C., Chandel, B.S. and Mondal, B. (2012) Isolation of bluetongue virus serotype 1 from Culicoides vector captured in livestock farms and sequence analysis of the viral genome sgment-2. Trans. Emerg. Dis., 59: 361-368.

9. Halder, A., Joardar, S.N., Parui, P., Banerjee, D., Kumar, V., Samanta, I. and Lodh, C. (2013) Prevalence of midges; potent vectors for bluetongue virus infection in West Bengal, India. Adv. Anim. Vet. Sci., 1(4S): 45-50.

10. Narladkar, B.W., Shastri, U.V. and Shivpuje, P.R. (1993) Studies on Culicoides spp. (Diptera: Ceratopogonidae) prevalent in Marathwada region (Maharashtra) and their host preferences. Indian Vet. J., 70: 116-118.

11. Sreenivasulu, V., Subba Rao, M.V., Reddy, Y.N. and Gard, G.P. (2004) Overview of bluetongue disease, viruses, vectors, surveillance and unique features: the Indian subcontinent and adjacent regions. Vet. Ital., 40(3): 73-77.

12. Anon. (2012) Annual Report of All India Network Programme on Bluetongue. $9^{\text {th }}$ Annual Review Meeting. Indian Council of Agricultural Research, New Delhi. p26.

13. Wheeler, E.B. (2003) Horse Stable ventilation. Chapter 7. In: Penn State Agricultural research and Cooperative Extension Publications. Produced by Information and Communication Technologies in the College of Agricultural Sciences. Pennsylvania State University. Available from: http://www.pubs.cas.psu.edu/freepubs/pdfs/ub039.pdf. Accessed on 23-01-2012.

14. Turnbull, J.E. and Huffman, H.E. Fan ventilation principles and rates as PLAN M 9700. Available from: http://www. cps.gov.on.ca/english/plans/E9000/9700/M-9700L.pdf NEW 87:06 Assessed on 27-07-2014.

15. Venter, G.J. and Meiswinkel, R. (1994) The virtual absence of Culicoides imicola (Diptera: Ceratopogonidae) in a light trap survey of the colder, high-lying area of the eastern Orange Free State, South Africa, and implications for the transmission of arboviruses. Onderstepoort J. Vet. Res., 61(4): 327-340.

16. Bianca, W. (1962) Relative importance of dry- and wetbulb temperatures in causing heat stress in cattle. Nature, 195:251-252.

17. Vision 2020. (1998) In: Perspective Plan Committee MAU, editor. Marathwada Agricultural University Parbhani Perspective Plan. Perspective Plan Committee MAU, Parbhani. p13-14.

18. Ehrlenbruch, R., Eknæs, M., Pollen, T., Inger Lise Andersen, I.L. and Boe, K.E. (2010) Water intake in dairy goats-the effect of different types of roughages. Ital. J. Anim. Sci., 9: 400-403.

19. Dawson, L. James, A. and Olcott, B. (2004) Meat goat herd health-procedures and prevention. In: Web based training and certification program for meat goat producers. Available from: http://www2.luresext.edu/goats/training/ qa.html. Accessed on 26-07-2014. 
20. Goetsch, A.L., Gipson, T.A., Askar, A.R. and Puchala, R. (2008) Invited review: Feeding behavior of goats. J. Anim. Sci., 88: 361-373.

21. Animut, G., Goetsch, A.L., Aiken, G.E., Puchala, R., Detweiler, G., Krehbiel, C.R., Merkel, R.C., Sahlu, T., Dawson, L.J., Johnson, Z.B. and Gipson, T.A. (2005) Grazing behavior and energy expenditure by sheep and goats co-grazing grass/forb pastures at three stocking rates. Small Rumin. Res., 59: 191-201.

22. Abdelsalam, M.M. and AL-Seaf, A.M. (2013) Behavioral aspects of Aradi and its first cross with Damascus goats throughout vital stages of their lives. J. Agric. Vet. Sci. 6: 3-16. Available from: http://www.publications.qu.edu.sa/ ojs/index.php/agriculture/article/download/./587. Accessed on 26-7-2014.

23. Prescriber, special issue No 18, Jan 2000. UNICEF publication with cooperation of WHO Available from: http://www. unicef.orgprescribereng_p18.pdf. Accessed on 21-12-2012.

24. FAO bulletin "Netting flies and mosquitoes protects livestock, boosts milk yields in Rome”. Published on 27 March 2013. Available from: http://www.fao.org/news/ story/en/item/173224/icode/www.egfar.org). Accessed on 26-06-2013.

25. Bouraoui, R., Lahmar, M., Majdoub, A., Djemali, M., and Belyea R. (2002) The relationship of temperature-humidity index with milk production of dairy cows in a Mediterranean climate. Anim. Res., 51: 479-491.

26. Abdel Rahman, I.M.K., Nagpaul, P.K. and Singh, B. (2013) Effect of two different shelter systems on milk yield and composition, feed intake, feed conversion efficiency and physiological responses in lactating crossbred goats during summer season. Egypt. J. Sheep. Goat Sci., 8(1): 81-87. Available from: http://www.easg.eg.net. Accessed on 26-07-2014.

27. Morrison, S.R. (1983) "Ruminant heat stress: effect on production and means of alleviation." J. Anim. Sci., 57: 1594-1600.

28. Dahlanuddin, T.C.J. and Hill, M.K. (1996) Effects of increasing ambient temperature on the intake and digestibility of high- and low-quality feedstuffs in goats. J. Anim.
Physiol. Anim, Nutr., 75: 185-191.

29. Patil, R.A., Karanjkar, L.M., Jadhav, V.S., Hanmante, A.A. and Narwade, S.G. (2005) Effect of housing patterns on microclimate and water intake in osmanabadi weaned kids. Vet. World, 1: 144-146.

30. Srikandakumar, A., and Johnson, E.H. (2004) Effect of heat stress on milk production, rectal temperature, respiratory rate and blood chemistry in Holstein, Jersey and Australian milking Zebu cows. Trop. Anim. Health Prod., 36: 685-692.

31. Silanikove, N. (2000) Effects of heat stress on the welfare of extensively managed domestic ruminants. Livest. Prod. Sci., 67: 1-18.

32. Cook, N.B., Bennett, T.B. and Nordlund, K.V. (2005) Monitoring indices of cow comfort in free-stall-housed dairy herds. J. Dairy Sci. 88: 3876-3885.

33. Metcalf, J.A., Roberts, S.J. and Sutton, J.D. (1992) Variations in blood flow to and from the bovine mammary gland measured using transit time ultrasound and dye dilution. Res. Vet. Sci., 53: 59-63.

34. Calvete, C., Estrada, R., Miranda, M.A., Del Rio, R., Borrás D., Beldron F.J., Martínez A., Calvo, A.J. and Lucientes J. (2010) Protection of livestock against bluetongue virus vector Culicoides imicola using insecticide-treated netting in open areas. Med. Vet. Entomol., 24(2): 169-75.

35. Furtado, D.A., Carlos, A.V.G., Medeiros, A.N., Edgard, C.P.F. and Valdi, L.Jr. (2008) Effect of the thermal environment and supplementation of the physiological variables in the Moxotó goats. Engenharia Agrícola., 28: 396-405.

36. Silva, R.G. (2000) In: Introduction to Biolclmatology. Nobel, Sao Paulo. p286.

37. Teixeira, M.C. and Modesto, E.C. (2005) Physiological parameters of heifers kept in irrigated grazing system in the semi-arid Northeast. In: Annual Meeting of the Brazilian Society of Animal Science, 42, 2005, Goiânia. Anais. Goiânia: Brazilian Society of Animal Science, CD-ROM.p1.

38. Webster, A.J.F. (1983) Environmental stress and the physiology, performance and health of ruminants. J. Anim. Sci., 57: 1584-1593. 